

\section{Litteratur i Bhutan}

Anne Burchardi

Til middag hos Werner Best

Gunnar Larsen

Toldruller og tågesignaler, regnskaber og revyviser

Therese Høgh Jacobsen

Bovrup-Kartoteket - et boghistorisk studie

Anders Otte Stensager

Kronik \& Publikationer

Udgiver: Det Kongelige Bibliotek

Redaktion, grafisk tilrettelæggelse:

Afdelingsbibliotekar Lotte Philipson

\section{Redaktionsråd:}

Direktør Erland Kolding Nielsen, Forskningschef John T. Lauridsen

Konceptdesign: Kontrapunkt A/S

Pris: Abonnement. Kr. 125,- årligt (fire numre).

Tilmelding via tel 33474315 eller email jl@kb.dk.

Løssalg. Kr. 50,-. Kan købes i Diamantboghandelen

Medlemmer af Diamantklubben, Det Kongelige Biblioteks

kulturklub, modtager tidsskriftet som en af medlemsfordelene.

Oplag: 2.850

Tryk: Rødgaard - grafisk produktion

Trykt på miljøgodkendt papir, som opfylder kravene i ISO 9706 om langtidsholdbart papir

Hvor intet andet angives, er eftertryk tilladt med angivelse af kilde og evt. forfatter.

ISSN: 0905-5533 


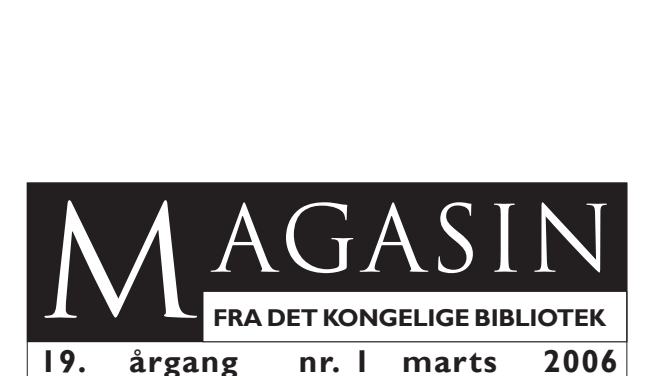


